\title{
Pacifier Sucking Habit and its Relation to Dental Caries and Type of Feeding Habits among Group of Children (Comparative Study)
}

\author{
AseelHaidar Al-Assadi ${ }^{1}$, Zainab A.A. Al-Dahan ${ }^{2}$ \\ ${ }^{1}$ Assistant Professor, Pedodontic and Prevention Department, College of Dentistry, Baghdad University \\ ${ }^{2}$ Professor, Pedodontic and Prevention Department, College of Dentistry, Baghdad University
}

\begin{abstract}
Objective: This study was conducted to investigate the severity of dental caries among children with pacifier sucking habit and to assess the effect of this habit on the type of feeding in those children. Methods: The study was carried out among 100 child aged 1-5 years old (50 children with continuous pacifier sucking habit (study group), compared to 50 children without any sucking habit (control group) matching the study group in age and gender). The parents were asked to fill an information sheet concerning general health and type of feeding of their children. Clinical examination were done for both groups of children (study and control) to determine their caries activity. Results: The prevalence of dental caries was $56 \%$ for the total pacifier sucking children, however, it was only $10 \%$ in the non-pacifier sucking children. This study demonstrated that $8 \%$ of pacifier sucking children were breast fed compared to $70 \%$ of non- pacifier sucking children, meanwhile bottle feeding was the predominant feeding type among pacifier sucking children. Conclusion: A significant difference was present between the two groups in caries experience of primary dentition by which the pacifier sucking group demonstrated higher caries experience. Breastfeeding was predominant among the non-pacifier sucking group, whereas bottle feeding was the predominant among pacifier sucking children.
\end{abstract}

Keywords: pacifier, dental caries, type of feeding

\section{Introduction}

In infants and toddlers, non-nutritive sucking habits are used to satisfy their psychological needs. A pacifier (dummy) sucking is one of the most common nonnutritive sucking habits. It is a nursing object that has an imperforated nipple, such a device used by many infants and children to provide a sense of comfort, security and pleasure ${ }^{(1,2,3)}$.

Great variations in the prevalence rate of pacifier sucking habits can be observed in different societies ${ }^{(1,4)}$ that may range according to the age of children ${ }^{(5)}$ from $68 \%$ among American infants aged 6 weeks and under ${ }^{(6)}$ to $26 \%$ at the age of 2 months to 7 years among the Finnish children ${ }^{(7)}$, however, it was $24.54 \%$ among Iraqi children 1-5 years old (8)

Prolonged pacifier sucking habit may produce deleterious effects $^{(9)}$,especially if it persists beyond 3 years of age ${ }^{(3)}$, including interruption of breast-feeding, or even its cessation $(4,10,11)$, recurrent otitis media ${ }^{(7)}$, candidal infection and thrush ${ }^{(12-14)}$.In addition, it may act as a predisposing factor that may increase the chance of developing dental caries ${ }^{(9,11)}$ as well as the development of posterior cross bite which is one of the most frequent type of malocclusion associated with its prolonged use ${ }^{(12-14)}$.

Since that there is no available Iraqi data or study concerning dental decay in relation to pacifier use, this study was conducted to investigate the relation of pacifier sucking habit to caries activity and the type of feeding among children aged 1-5 years old in Baghdad city.

\section{Material and Methods}

In order to carry out this study, approval from the ministries of work and social affairs, health and education was taken. At first, the purpose of the study was explained to the school authorities by a contact with them.A permission was obtained from the parents of children before including any child in this study by questionnaires designed to obtain information from them including their acceptance, general health,pattern of feeding practices and the sucking habits of their children. The study group was consisted of fifty healthy children with continuous pacifier sucking habit aged 1-5 years, they were selected from kindergarten and nursery schools in both sides of Baghdad city, in the other hand, the control group were 50 healthy children matching the age and gender of the study group and selected from the same school of the study group. They were without any sucking habit.

A clinical examination was conducted in the classroom; each child was examined while seated on his school chair under artificial light source. The dmft index was recorded in accordance with the WHO criteria for epidemiological studies ${ }^{(15)}$.

Statistical analyses were performed using SPSS package version 16. Student's t-test was applied for comparisons between the study and the control group. $(\mathrm{P}<0.05)$ was considered statistically significant.

\section{Results}

Concerning dental caries, $90 \%$ for the non-pacifier sucking group were caries free whereas only $44 \%$ was found among pacifier sucking group. Although the number of caries free children was higher among non-pacifier sucking group in all 


\section{International Journal of Science and Research (IJSR) \\ ISSN (Online): 2319-7064}

Index Copernicus Value (2015): 78.96 | Impact Factor (2015): 6.391

ages, there was no statistical difference between the two groups, Table (1), meanwhile the prevalence of dental caries was $56 \%$ for the total pacifier sucking children and $10 \%$ for the non-pacifier sucking children, Table (2). The mean dmft value for the pacifier sucking children was higher than that of non - pacifier sucking children in all ages, Fig. (1).

Table 1: Prevalence of dental caries among pacifier and non-pacifier sucking children

\begin{tabular}{|c|c|c|c|c|c|c|}
\hline \multirow{2}{*}{$\begin{array}{c}\text { Age } \\
\text { (Years) }\end{array}$} & \multirow{2}{*}{\begin{tabular}{c} 
No. \\
\cline { 3 - 7 }
\end{tabular}} & $\begin{array}{c}\text { Pacifier sucking } \\
\text { No. with } \\
\text { dental caries }\end{array}$ & $\%$ & $\begin{array}{c}\text { Non pacifier sucking } \\
\text { dental caries }\end{array}$ & $\%$ & Sig. \\
\hline $1-2$ & 21 & 3 & 14.28 & 0 & 0.00 & N.S.* \\
\hline $2-3$ & 15 & 11 & 73.33 & 1 & 6.66 & N.S. \\
\hline $3-4$ & 8 & 8 & 100 & 3 & 37.50 & N.S. \\
\hline $4-5$ & 6 & 6 & 100 & 1 & 16.66 & N.S. \\
\hline All ages & 50 & 28 & 56 & 5 & 10 & N.S. \\
\hline
\end{tabular}

* Not Significant, $\mathbf{P}>0.05$

Table 2: Percentage of caries free among the pacifier and non-pacifier sucking children

\begin{tabular}{|c|c|c|c|c|c|c|}
\hline \multirow{2}{*}{$\begin{array}{c}\text { Age } \\
\text { (Years) }\end{array}$} & \multirow[b]{2}{*}{ No. } & \multicolumn{2}{|c|}{ Pacifier sucking } & \multicolumn{2}{|c|}{ Non pacifier sucking } & \multirow[b]{2}{*}{ Sig. } \\
\hline & & $\begin{array}{c}\text { No. of } \\
\text { caries free }\end{array}$ & $\%$ & $\begin{array}{c}\text { No. of } \\
\text { caries free }\end{array}$ & $\%$ & \\
\hline $1-2$ & 21 & 18 & 85.7 & 21 & 100 & N.S. \\
\hline $2-3$ & 15 & 4 & 26.6 & 14 & 93.3 & N.S. \\
\hline $3-4$ & 8 & 0 & 0.0 & 5 & 62.5 & N.S. \\
\hline $4-5$ & 6 & 0 & 0.0 & 5 & 83.3 & N.S. \\
\hline All ages & 50 & 22 & 44 & 45 & 90 & N.S. \\
\hline
\end{tabular}

* Not Significant, $\mathbf{P}>\mathbf{0 . 0 5}$

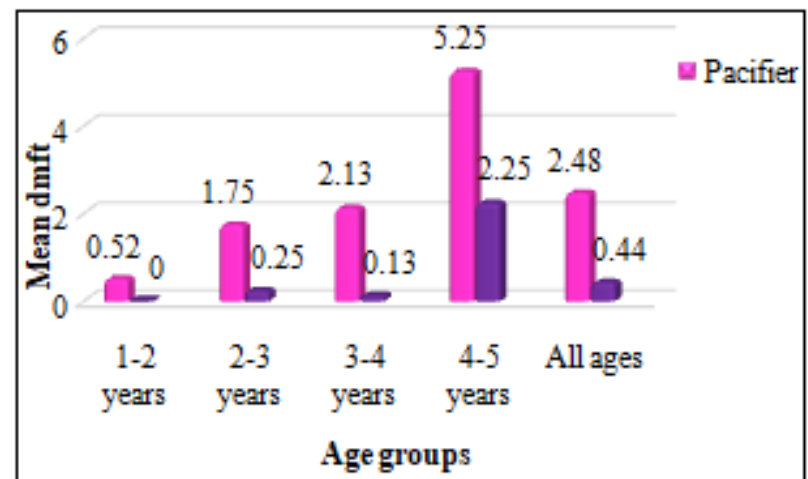

Figure 1: Caries experience (dmft) among pacifier and non pacifier suking children by age group.

In this study, (Table 3) demonstrates the distribution of children according to the method of feeding. The results showed that $8 \%$ of pacifier sucking children were breast fed compared to $70 \%$ of non-pacifier sucking, meanwhile bottle feeding was the predominant type among pacifier sucking children $(72 \%)$. Concerning mixed feeding (breast and bottle feeding), it was used by $20 \%$ of pacifier sucking group where it was $22 \%$ in non - pacifier sucking group.

Table 3: Distribution of children according to method of feeding

\begin{tabular}{|c|c|c|c|c|c|c|c|c|c|c|}
\hline \multirow{3}{*}{ Method of feeding } & \multicolumn{10}{|c|}{ Age group in years } \\
\hline & \multicolumn{2}{|c|}{$(1-2)(n=21)$} & \multicolumn{2}{|c|}{$(2-3)(n=15)$} & \multicolumn{2}{|c|}{$(3-4)(n=8)$} & \multicolumn{2}{|c|}{$(4-5)(n=6)$} & \multicolumn{2}{|c|}{ Total $(\mathrm{n}=50)$} \\
\hline & Pacifier & Non pacifier & Pacifier & Non pacifier & Pacifier & Non pacifier & Pacifier & Non pacifier & Pacifier & Non pacifier \\
\hline \multirow{2}{*}{ Breast feeding } & 1 & 14 & 1 & 11 & 1 & 7 & 1 & 3 & 4 & 35 \\
\hline & $4.76 \%$ & $66.67 \%$ & $6.67 \%$ & $73.33 \%$ & $12.5 \%$ & $87.5 \%$ & $16.67 \%$ & $50 \%$ & $8 \%$ & $70 \%$ \\
\hline \multirow{2}{*}{ Bottle feeding } & 15 & 3 & 11 & 0 & 5 & 0 & 5 & 1 & 36 & 4 \\
\hline & $71.43 \%$ & $14.29 \%$ & $73.33 \%$ & - & $62.5 \%$ & - & $83.33 \%$ & $16.67 \%$ & $72 \%$ & $8 \%$ \\
\hline \multirow{2}{*}{ Mixed feeding } & 5 & 4 & 3 & 4 & 2 & 1 & 0 & 2 & 10 & 11 \\
\hline & $23.81 \%$ & $19.05 \%$ & $20 \%$ & $26.67 \%$ & $25 \%$ & $12.5 \%$ & - & 33.33 & $20 \%$ & $22 \%$ \\
\hline P value & & H.S. & & H.S. & & H.S. & & N.S. & & H.S. \\
\hline
\end{tabular}

* Not Significant, $\mathrm{P}>0.05$

** Highly significant, $\mathrm{P}<0.01$

\section{Discussion}

Since there are no previous studies concerning dental caries among pacifier sucking children in Iraq, therefore comparison was done only with studies conducted in other parts of the world. Moreover, it is difficult to cross match the results because of the wide variety of methods usedto investigate the incidence of dental caries among different age groupsin different environments. The total caries experience is demonstrated by (dmft) index which is a wellaccepted measure of caries prevalence throughout the world. In the present study the incidence of dental caries is higher among pacifier sucking group (56\%) than it is among nonpacifier sucking group which is only (10\%), Table (2).

One of the microorganisms responsible for dental caries is lactobacilli which are aciduricacidogenic bacteria that present in large number in the mouths of pacifier sucking children.Salivary lactobacilli counts are useful in the prediction of future cariesactivity. The use of pacifier increase the occurrence of salivary lactobacilli and it could therefore be a factor influencing caries susceptibility and activity in children ${ }^{(12,14,16)}$. In addition, pacifier use often associated with a negligent attitude toward the child's tooth brushing ${ }^{(17)}$.

The results revealed that breast feeding was predominant in non-pacifier sucking group (70\%) than pacifier sucking group (8\%), Table (3), this finding is in accordance with other studies ${ }^{(18,19)}$, children will less likely to have been exclusively breastfed if they use of pacifier early in infancy.

In general and as a consequence of increasing breast feeding in non-pacifier sucking group, there is a decrease in bottle feeding observed in this study $(8 \%)$ compared to $(72 \%)$ of pacifier sucking children, Table (3). The presence of high percentage of bottle feeding among pacifier sucking group may be due to their accommodation on the artificial nipple

\section{Volume 6 Issue 7, July 2017 www.ijsr.net}




\section{International Journal of Science and Research (IJSR) \\ ISSN (Online): 2319-7064}

Index Copernicus Value (2015): 78.96 | Impact Factor (2015): 6.391

of the pacifier on one hand and the presence of the enlarged hole at the end of the nipple of the bottle which make the feeding more easier for the child and so the child reject the breastfeeding.

Among non-pacifier sucking group the results revealed that there is a going back for the mothers to breast feeding (70\%) and in comparison with other Iraqi studies it was $24 \%$ by AL- Wehebin $1991^{(20)}$ and $51.5 \%$ by AL-Mukhtar $1995^{(21)}$.

The difference between the three studies may be due to the unjustified sanctions that were imperatively imposed on our country which lead to sever shortage in the amount of milk, and also its price had gone up very high that make it unavailable to the children and also may be due to the age difference between the present study and the previous studies. This increase in the breastfeeding may be due to health education of the mothers toward breastfeeding which is healthier and the mother's milk is well balance diet for the child, more sterile, ready to give to the baby, and protect babies against infection and this is in agreement with recommendation of WHO in $1991^{(22)}$ about the importance of breastfeeding.

\section{References}

[1] Warren JJ, Levy SM, Nowak AJ, Tang S. Nonnutritive suckingbehaviors in preschool children: a longitudinal study. PediatrDent. 2000; 22:187-191.

[2] Maguire JA. The evaluation and treatment of pediatric oral habits. DentalClin. North Am. 2000; 44(3): 659669.

[3] Maia-Nader M, Figueiredo CSA, Figueiredo FP, Silva AAM, Thomaz EBA, Saraiva MCP,Barbieri MA, Bettiol H. Factors associated with prolonged nonnutritive sucking habits in two cohorts of Brazilian children. 2014; 14:743-753.

[4] Moimaz SA, Zina LG, Saliba NA, Saliba O. Association between breastfeedingpractices and sucking habits: a cross-sectional study of childrenin their first year of life. J Indian SocPedodPrev Dent 2008, 26:102106.

[5] Hanafin S, Griffiths P. Does pacifier use cause earinfections in young children? BritishJournal ofCommunity Nursing 2002; 7(4): 266-11.

[6] Howard CR, Howard FM, Lanphear B. The effect ofearly pacifier use in breast feeding duration. Pediatrics 1999; 103: 33.

[7] Niemelä M, Uhari M, Mottonen M. A pacifierincreases the risk of recurrent acute otitis media inchildren in day care centers. Pediatrics 1995; 96: 884 - 8.

[8] Al-Assadi AH, Al-Dahan ZAA. Prevalence of pacifier sucking habit and its effect on occlusion in children aged 1-5 years in Baghdad city. J BaghColl Dentistry 2015; 27(4):143-146).

[9] Warren JJ, Bishara SE: Duration of nutritive and nonnutritive suckingbehaviors and their effects on thedental arches in the primarydentition. Am J OrthodDentofacialOrthop 2002, 121:347-356.

[10] Viviane V. Degan, Regina M. Puppin- Rontani. Prevalence of Pacifier-sucking Habits and Successful Methods to Eliminate Them-A Preliminary. Study Journal of Dentistry for Children- 2004; 71:2, 148-151
[11] Victra CG, Tomasi E, Olinoto MTA, Barros FC. Use of pacifiers is associated with decreased breast feeding duration. Pediatrics 1995; 95(4): 497-9.

[12] Ollila P, Niemela M, Uhari M, Larmas M. Risk factors for colonization of salivary lactobacilli and Candida in children. ActaOdontolScand 1997; 55(1): 9 - 13.

[13] Niemela M, Pihakar O, Pokka T, Uhari M. Pacifier as a risk factor for acute otitis media. A randomized controlled trial of parental counseling. Pediatrics 2000; 106: 483-8.

[14] Al-Assadi AH, Al-Dahan ZAA, Al- Rammahy A. Pacifier Sucking Habit and its Relation to Oral Health of Children Aged 1-5 Years (comparative study)Iraqi Dental Journal 2016; 38(2): 90-94.

[15] WHO (World Health Organization) (1987): Oral health survey, basic methods, 3rd ed., WHO, Geneva.

[16] Yonezu T and Yakushiji M. Longitudinal study on influence of prolonged non-nutritive sucking habits on dental caries in Japanese children from 1.5 to 3 years of age. Bull Tokyo Dent Coll. 2008; 49(2):59-63.

[17] Paunio P; Rautava P; Sillanpaa M. The finish family competence study: The effects of living conditions on sucking habits in 3 years old finish children and the association between these habits and dental occlusion. ActaOdontol. Scand 1993; 51(1): 23-9.

[18] 18. Zakarija-Grković I, Šegvić O, Vukušić AV, Lozančić T, Božinović T, Ćuže A, Burmaz T. Predictors of suboptimal breastfeeding: an opportunity for public health interventions. Eur J Public Health 2016; 26 (2): 282-289.

[19] Ghotbi1 F, Naseh A, Azargashb E, Naraghi SHA, Sene AA. Risk Factors for Early Discontinuation of Breastfeeding in Iranian Mothers. Journal of Obstetrics and Gynecology, 2016, 6, 606-614.

[20] Al - Wehab A. Dietary habits and its relationship to caries experience. (1991) M.Sc. Thesis University of Baghdad.

[21] Al - Mukhtar B.S. Prevalence of dental caries among pre - school children in relation to infant feeding habits in Mosul city. (1995) M.Sc. Thesis University of Baghdad.

[22] WHO (World Health Organization) (1991) Helping mothers to breast feed. WHO Geneva.

\section{Volume 6 Issue 7, July 2017 www.ijsr.net}

